\title{
Pre-School Teachers' Understanding about Children's Self-Directed Learning
}

\author{
Liga Aboltina Dr. paed. \\ University of Latvia, Latvia \\ liga.aboltina@lu.lv
}

\begin{abstract}
As society evolves, the need for a paradigm shift from teaching-centred to learning-centred education has become stronger. The learning processes focus on how children learn instead of how teachers teach, and it requires children to take responsibility for their own learning, thus promoting self-affirmation and self-directed learning. Implementation of a competency-based learning approach requires improving transversal skills, including self-directed learning. Unfortunately, preschool teachers lack a common understanding about children's self-directed learning. It is still a habit to set the goal of lessons to provide ready knowledge to lead and control the learning process. Observations in preschool classes show that teachers often do not have sufficient understanding on how to organize and process self-directed learning. In various studies self-directed learning is mainly based on the experience of schools and universities, associating preschools with school practice and researches. Schools and teachers are challenged to promote children's self-directed learning. The aim of the paper is to identify the understanding of preschool teachers about self-directed learning in preschool and to find out the criteria for self-directed learning. Research methods used was content analysis of scientific literature and sources and survey of teachers. The research results indicate that preschool teachers relatively understand the essence of self-directed learning and determine the need for preschool teachers to promote children's self-directed learning in preschools.
\end{abstract}

Keywords: motivation, preschool child, self-directed learning, self-management, self-monitoring, preschool education.

\section{Introduction}

It is important for today's children to be open for change by getting fully involved and focused on the learning process, by having self-discipline, by controlling their behaviour and emotional state, by performing self-analysis in the process of self-directed learning, in which thinking occurs on a cognitive and metacognitive level (Zimmerman, 2002).

Self-directed learning is a key competency that children must develop from the age of three or four. These competencies should be integrated into all areas where new knowledge and skills are being acquired (Council of the European..., 2002; Dignath, Buettner, Langfeldt, 2008).

In pedagogical work, it is necessary to further develop children's independent research skills, notice causation and draw conclusions by gaining new experience and knowledge (Taurina, 2015). It is important to respect the learner's freedom or autonomy in the educational process and the regularities of teaching and learning (Badjanova, Ilisko, 2014).

Thus, the 21 st century presents a need for new knowledge, skills, habits and values in preschool and school learning contents, by developing competency models (Mooij et al., 2012) to set different educational goals related to changes in the development of society.

In areas of activities, it is important for people to alternate competences with transversal skills in different ways, including self-directed learning. It covers all areas that have not been sufficiently addressed in the curriculum so far, thus emphasizing the development of value-based habits, namely, the planning and management of one's own learning activities.

There is still fragmentarism, duplication and lack of cohesion in the curriculum content and learning process. Unnecessary emphasis is placed on the acquisition of isolated, passive knowledge, and the curriculum is insufficiently related to real life situations. In the curriculum of 2006 (Recommendation of the..., 2006) the learning aspects have already been formulated. These aspects conceptually correspond to self-directed learning skills and their development is provided by the guidelines for preschool education. However, observations and analysis of preschool activities show that self-directed learning skills have not been strengthened in everyday practice and need to be promoted. 
As studies show, compared to other levels of education self-directed learning in preschools is the least studied (Todd, Douglas, 2012; Mooij et al., 2012; Mooij, Driessen, 2008). Studies on self-directed learning in preschool place particular emphasis on the idea that children learn better if the experience is gained through self-directed activities and they can control their own experience (learning is self-directed), but the reasons have not been explored yet. Self-directed activity is identified in connection with the acquisition of technology in preschool and is studied as a self-regulated activity. According to researchers, a common international vision is needed to promote children's self-directed learning using technology in preschool (Mooij et al., 2012).

Based on the above, it can be concluded that although self-directed learning should be promoted in preschool, there is a lack of several studies that would identify how to implement it. In order for a teacher to be a facilitator of a child's self-directed learning (Minkyoung, 2018; Birenbaum, 2002), who takes over learning and thinking activities from students in a self-directed learning process, it is necessary to identify teachers' understanding about self-directed learning in preschool. Hence, the aim of the research is the following - to find out the understanding of preschool teachers about self-directed learning in preschools and to identify the criteria of self-directed learning.

\section{Research methodology}

The following tasks were set for the study:

- to develop an analysis of the theoretical literature of self-directed learning;

- to carry out a study of preschool teachers about self-directed learning in preschools;

- to identify the criteria of self-directed learning.

The research question was put forward - how do preschool teachers explain and describe children's selfdirected learning?

The qualitative content analysis of scientific literature was carried out in the research, as well as an empirical study was conducted using a survey of respondents. Preschool teachers explain the term "self-directed learning", naming the preconditions that promote self-directed learning, indicate the criteria for self-directed learning and justify the need for children's self-directed learning. All survey questions are open-ended. The survey explored the explanation of self-directed learning, the rationale for developing self-directed learning skills, the criteria for self-directed learning and the preconditions for self-directed learning.

Microsoft Excel data processing program was used for processing and analysis of the obtained data. The research base consists of 55 preschool teachers of different age groups from different preschool education institutions (Table 1). The largest number of respondents were of age 26 to 40, having an average length of work experience of 16 years. This shows that the majority of respondents have work experience with preschool children and they have gained an understanding of self-directed learning in their work environment and teacher professional development courses.

Table 1

\section{Theoretical framework of self-directed learning}

Self-directed learning occurs when a child learns proactively. This means that the child does not react passively to the teacher's instructions, but does something himself before learning a new topic and is constantly and actively involved in the learning process (Zimmerman, 2002; Lindner, Harris, 1992).

Self-directed learning means the ability to assimilate new knowledge and use the knowledge to solve problems, and the ability to self-evaluate and think critically, as well as to communicate and cooperate with others (Robinson, Persky, 2020; Cornish, 1986; Resnick, 1987).

Self-directed learning offers various benefits in the learning process. Self-directed learning helps children to develop their own effective learning ways depending on their learning style, speed, interests, goals and other factors. There is growing evidence that individuals who take the initiative to study, they usually learn 
more better and deeper than those who are passive and dependent on their own learning. It is important to give learners more power over what to learn, when to learn and how much to learn (Minkyoung, 2018).

Self-directed learning also includes the transfer of conscious learning or metacognitive (thinking management) activities related to self-management by planning, forecasting, monitoring, adjusting, evaluating and reviewing (Miller-Keane, O'Toole, 2005). Thus, self-directed learning is closely related to the concepts of self-regulated learning, self-planned learning, and autonomous learning. Self-regulated learning is a concept oriented on the process, according to which learners monitor and evaluate their learning and behaviour to achieve their goals. Self-planned learning is defined as the learner's deliberate attempt to acquire specific knowledge and/or skills, and the learner is responsible for decisions and rules regarding learning activities. Autonomous learning, sometimes referred to as student learning, refers to a shift in focus in the classroom from teaching to learning, where students are actively involved in the process of building knowledge through their prior knowledge and learning strategies. Although all these concepts emphasize autonomy, they do not mean that learners carry out all their activities in complete independence. In teacher-led learning, the learner depends on the teacher who is taking full responsibility for what needs to be taught. Moreover, in the teacher-led learning perspective, the learner's experience is less valued than the teacher's experience, while the self-directed learning perspective considers the learner's experience to be an increasingly rich learning resource. Teacher-centred learning is usually subjectcentred, while self-directed learning is usually focused on a task or challenge (Minkyoung, 2018).

In preschools and schools studies on self-directed learning have been carried out in interaction with children's age. In many European countries, preschool and primary school activities are organized according to the children's age, when learning tasks or activities are usually adapted to the average age. This is the case, for example, in Germany (Leistung und Versagen..., 1980; Händel, Vialle, Ziegler, 2013), the United Kingdom (Tymms, Merrel, Henderson, 2000; Wheadon, 2013; Norwich, Ylonen, GwernanJones, 2014), the USA (Earle, 2001; Colangelo, Assouline, Gross, 2004a, 2004a; Lillard, 2012) and the Netherlands (Hermanns, 1979, 1980; Mooij et al., 2012). This usually means that most of the tasks or activities correspond to most of the children in the group or class. For talented and less talented children, the offered games and learning activities do not correspond to their level of psychological development. This discrepancy also means that these children are less responsible, less able to regulate their activities and less ready for self-directed teaching (Kemp, 2000; Meijer, 2003; Mooij, Driessen, 2008).

Summarizing the above mentioned, the essence of self-directed learning consists of three dimensions that are closely related to each other: self-management, self-monitoring and motivation. In the self-management phase planning is the main activity, when the child thinks about the results to be achieved and considers the strategies to achieve goals, creates a learning plan. Self-management is a collaborative experience in which children use teacher support, learning materials and communication with others. In the self-control phase, the child implements his plan and monitors his progress towards achieving the goal. The child may decide to change strategies. This phase determines how well the chosen strategies help him to achieve the learning goals. Self-control focuses on cognitive and metacognitive processes. Responsibility for self-control reflects the learner's commitment through critical reflection and collaboration. Self-control depends on both internal and external feedback. Motivation plays an important role in promoting learning efforts and achievements in making decisions about the choice of learning goals, and in trying to stay on the task and continue work that is closely linked to self-control and own will (Minkyoung, 2018). A child is considered to have good self-directed learning skills, if he is able to motivate himself to learn, manage his emotions, plan, analyse and evaluate his learning outcomes (Veenman et al., 2014; Azevedo, Aleven, 2013).

Based on the analysis of the self-directed learning theory (Schunk, Zimmerman, 2011; Miller-Keane, O'Toole, 2005; Reece, Walker, 2016), learning is considered as a component of deep learning and thus analysed in an empirical study based on the following learning activities: think, understand, know, collaborate, use, and make sure.

\section{Research results and discussion}

Due to the research, $29 \%$ of preschool teachers explain self-directed learning activities as independent and $27 \%$ as active, when children set their own tasks, carry them out and thus learn and manage their activities. Children are the initiators, supervisors and facilitators of their own actions to meet their learning needs. A smaller number of respondents $(11 \%)$ indicate the child's cognitive processes as the most 
important in the explanation of self-directed learning, which shows that children are not offered tasks and problems to the extent that would facilitate their thinking processes. Therefore, it can be assumed that preschool teachers do not offer children enough tasks on different thinking levels. Preschool teachers (8\%) indicate that children in self-directed learning acquire new knowledge and skills by trying, experimenting, researching, making mistakes and drawing conclusions. This expresses the probability that children do not have a sufficiently stimulating and supportive learning environment that would reflect the learning process and encourage action, and that could encourage children to cognize and learn, thus facilitating the acquisition of "active" information. An equal number of respondents (6\%) mentioned interest, motivation and self-organization in the explanation of self-directed learning. Cognitive interest determines the child's motivation, which in turn ensures the promotion of achievements, decision-making on the result to be achieved (learning goals), as well as promotes self-control and own will. Self-organization is a characteristic of a personality to purposefully mobilize oneself, to actively use all one's possibilities in the achievement of goals and in interaction with self-management. Thus, by proposing independent and active activity as a component of self-directed activity, it can be concluded that preschool teachers do not associate it with the child's self-organization. Only $5 \%$ of teachers emphasize self-directed activities as a search for information, $4 \%$ note feedback, while 3\% indicate self-regulation of one's behaviour, and only $1 \%$ - cooperation. This indicates that preschool teachers perceive and understand self-directed learning in a fragmentary way. Thus, it can be concluded that preschool teachers lack a deeper understanding about essential self-directed learning components and their interrelationships.

Analysis shows that $38 \%$ of preschool teachers note the learning environment as one of the preconditions that promote self-directed learning, meaning the material base (arrangement of appropriate environment, visuals, cognitive materials, various games) and its accessibility. A part of the respondents (21\%) emphasized an interested, encouraging and supportive teacher. The child interacts with human resources that is also a component of the learning environment. Preschool teachers explain this as a separate precondition for self-directed activity. An appropriate learning environment meaningful, changeable and cognitive - is a prerequisite for promoting self-directed learning. Only a few teachers' responses mention time, which is an important precondition for children to be able to learn on their own, especially by promoting the cognitive processes through which the child acquires and processes information to manage his or her activities.

Preschool teachers (16\%) emphasize the child's interest and motivation as a precondition, pointing out that only a motivated child will show interest in the work to be done. Motivation, in turn, is related to the cognitive and metacognitive processes that contribute to the implementation of the results to be achieved and to overcome the difficulties and obstacles that arise due to implementation. The results of the survey show that preschool teachers explain the child's motivation in interaction with the teacher's activities, more specifically, that motivation stems from the child's interest and support. Based on the summarised teachers' answers, all that remains to be discussed is how to ensure an appropriate learning environment in the practice of preschool education institutions that promotes children's self-directed learning.

Although independent activity is mentioned the most in the explanation of self-directed learning, $11 \%$ note children's independence as a precondition for self-directed learning, which shows that independent activity is actualized in the process of self-directed learning, but relatively understood as a component influencing self-directed learning. Only $8 \%$ of preschool teachers mention a clear result to be achieved and $6 \%$ mention a process oversight to promote self-directed learning. If the result to be achieved is not formulated, the child cannot plan and implement action steps, that is, monitor and evaluate the progress - how successfully he / she has achieved the expected result.

As criteria for self-directed learning most preschool teachers indicate achieved results (19\%) and planning $(18 \%)$. Thus, it can be concluded that teachers indicate the result to be achieved and planning as a feature of self-directed learning, but in practice there is a lack of understanding of how the result to be achieved and planning would affect children's self-directed learning. Preschool teachers (15\%) mention the identification of the necessary resources, which is in line with the preconditions of self-directed learning, that is, the arrangement of an appropriate learning environment, accessibility and an interested, encouraging and supportive teacher. Twelve percent of preschool teachers indicate self-regulation of emotions and $13 \%$ - supervision, which correlates and describes a similar phenomenon as before, i.e., teachers name self-regulation and supervision as a feature of self-directed learning, but relatively connect 
its influence with the child's self-directed learning. Nine percent of respondents mention reflection as a criterion of self-directed learning with the help of which the child guides his / her learning. Seven percent of respondents mention feedback as a criterion for evaluating his / her activity in the process and at the end of it. In order for a child to be able to direct his / her learning, he / she must be able to manage his / her emotional, behavioural and thinking processes (attention, memory, problem-solving processes), judge his / her thinking and further learning activities. For this to happen, the child must be able to reflect or consider seriously his or her thinking and, consequently, learning activities. Reflection is the basis for planning in which the child directs (plans, monitors and evaluates) his or her learning through questioning.

Feedback as a criterion for self-directed learning correlates with the preconditions for self-directed learning, that is, only a few preschool teachers name feedback as a feature of self-directed learning and understand its impact on the child's self-directed learning process. It is debatable how to provide feedback in the preschool pedagogical process so that it promotes children's self-directed learning.

The highest percentage of preschool teachers $(28 \%)$ mentions cognitive processes in the substantiation of self-directed learning skills. This means that self-directed learning promotes children's thinking, reasoning and analysis skills, as well as the child's attitude towards things that are reflected in the expression of opinion. This is in line with the studies analysed in the theoretical framework, confirming that the promotion of cognitive processes provides concentration and problem solving (Zimmerman, 1989; Pintrich, 2000; Randi, Corno, 2000; Minkyoung, 2018).

Similar to several studies (Hartman, 2001; Schraw, Kent, Kendall, 2006) $23 \%$ of respondents indicate that self-directed learning skills provide readiness for life activities that include all following: independent activity $(19 \%)$, self-regulation $(16 \%)$ by managing their behaviour, and self-organization (14\%), that is, plan, organize, take responsibility, make decisions.

It follows from the above that in general preschool teachers only partially understand and are aware of children's self-directed learning opportunities, which is confirmed by the different answers on selfdirected learning comprehension (Table 2).

\section{Conclusions}

1. Self-directed learning is described in the analysis of theoretical approaches as a component of in-depth learning and analysed in the study based on a self-regulated learning activities, what include self-discipline, emphasizing the development of value-based habits, planning of own learning activities, respecting the learner's freedom and autonomy. The essence of self-directed learning consists of three dimensions that are closely related to each other: self-management, self-monitoring and motivation.

2. In the empirical research pre-school teachers' understanding of self-directed learning in preschool has been identified:

a) most preschool teachers only partially understand the essence of self-directed learning; they emphasize children's independence, activity and initiative, but contrary to what is analysed in the theoretical framework, it is not associated with children's self-regulation;

b) preschool teachers name the following criteria of self-directed learning: the results to be achieved, planning, self-regulation and supervision. However, there is a lack of understanding of the interrelationships and interactions of these components; it means that they name the criteria of self-directed learning, but do not understand how the mentioned criteria affect children's self-directed learning;

c) the research data show that preschool teachers lack a deeper understanding of the components of the learning environment and their interaction in the process of children's self-directed learning. 
3. Referring to the theoretical framework of the study, to encourage children to try, experiment, study, make mistakes and infer in the process of self-directed learning, it is necessary to provide a stimulating and supportive learning environment that reflects the learning process and encourages the child to act.

4. Summarizing the theoretical findings about self-directed learning and the results of empirical research, it can be concluded that children's self-directed learning in the practice of preschool teachers should be promoted by ensuring mutual learning of teachers - collectively planning, organizing, observing and analysing classes, sharing experiences, reflecting on feedback on the process and the result.

\section{Bibliography}

1. Azevedo R., Aleven V. (2013). Metacognition and Learning Technologies: An Overview of Current Interdisciplinary Research. In R. Azevedo, V. Aleven (Eds.), International Handbook of Metacognition and Learning Technologies. Springer International Handbooks of Education, 28, 1-16. New York, NY: Springer. doi: 10.1007/978-1-4419-5546-3_1

2. Badjanova J., Ilisko Dz. (2014). Holistic philosophy based teaching approaches in Latvian primary schools: Primary education teachers' view. In V. Dislere (Ed.), The Proceedings of the International Scientific Conference Rural Environment. Education. Personality (REEP), 7. Jelgava: LLU, 22-28. Retrieved from https://llufb.llu.lv/conference/REEP/2014/Latvia-UnivAgricult-REEP-2014proceedings-22-28.pdf

3. Birenbaum M. (2002). Assessing Self-directed Active Learning in Primary Schools. Assessment in Education: Principles, Policy \& Practice, 9(1), 119-138. doi: 10.1080/09695940220119229

4. Colangelo N., Assouline S.G., Gross M.U.M. (2004a). A Nation Deceived: how schools hold back America's brightest students. The Templeton National Report on Acceleration, 1. Iowa City, IA: The Connie Belin and Jacqueline N. Blank International Center for Gifted Education and Talent Development. Retrieved from https://files.eric.ed.gov/fulltext/ED535137.pdf

5. Colangelo N., Assouline S.G., Gross M.U.M. (Eds.). (2004b). A Nation Deceived: how schools hold back America's brightest students. The Templeton National Report on Acceleration, 2. Iowa City, IA: The Connie Belin and Jacqueline N. Blank International Center for Gifted Education and Talent Development. Retrieved from https://files.eric.ed.gov/fulltext/ED535138.pdf

6. Cornish E. (1986). Educating children for the 21st century. Curriculum Review, 25(4), 12-17.

7. Council of the European Union. (2002). Council resolution 27 June 2002 on lifelong learning, in Official Journal of the European Communities, C 163, 09. Retrieved from https://eurlex.europa.eu/LexUriServ/LexUriServ.do?uri=OJ:C:2002:163:0001:0003:EN:PDF

8. Dignath C., Buettner G., Langfeldt H.P. (2008). How can primary school students learn selfregulated learning strategies most effectively?: A meta-analysis on self-regulation training programmes. Educational Research Review, 3(2), 101-129. doi: 10.1016/j.edurev.2008.02.003

9. Earle R.S. (Ed.). (2001). Standards for the Accreditation of Programs in Educational Communications and Instructional Technology (ECIT) (4 ${ }^{\text {th }}$ rev. ed.). Bloomington, IN: Association for Educational Communications and Technology (AECT). Retrieved from https://nanopdf.com/download/standards-5aecd76874966_pdf

10. Hartman H.J. (Ed.). (2001). Metacognition in Learning and Instruction: Theory, Research and Practice. doi: 10.1007/978-94-017-2243-8

11. Händel M., Vialle W., Ziegler A. (2013). Student Perceptions of High-achieving Classmates. High Ability Studies, 24(2), 99-114. doi: 10.1080/13598139.2013.843139

12. Hermanns J. (1979). Het ontstaan van Schoolproblemen. Een longitudinaal onderzoek in kleuteren lagere school [Emergence of Problems at School. A Longitudinal Study in Preschool and Primary School]. Pedagogische Studiën, 56, 348-357. Retrieved from https://objects.library.uu.nl/reader/index.php?obj=1874205368\&lan=en\#page//63/28/64/6328647945723956149785822347466704539.jpg/mode/1up (in Dutch)

13. Hermanns J. (1980). Het ontstaan van Schoolproblemen (II). Gedragsobservatie door kleuterleidsters [Emergence of Problems at School (II). Behavioural Observation by Preschool Teachers], Pedagogische Studiën, 57, 11-21. Retrieved from 
https://objects.library.uu.nl/reader/index.php?obj=1874-

205374\&lan=en\#page//39/26/60/39266079381480898686713843962403543630.jpg/mode/1up (in Dutch)

14. Kemp J.E. (2000). An Interactive Guidebook for Designing Education in the 21st Century. Bloomington, IN: TECHNOS of the Agency for Instructional Technology in partnership with Association for Educational Communications and Technology.

15. Leistung und Versagen: Alltagstheorien von Schülern u. Lehrern [Performance and failure: school teachers everyday theories]. (1980). Arbeitsgruppe Schulforschung. Munich: Juventa-Verlag. (in German)

16. Lillard A.S. (2012). Preschool Children's Development in Classic Montessori, Supplemented Montessori, and Conventional Programs. Journal of School Psychology, 50(3), 379-401. doi: 10.1016/j.jsp.2012.01.001

17. Lindner R.W., Harris B. (1992). The Development and Evaluation of a Self-Regulated Learning Inventory and Its Implications for Instructor-Independent Instruction. Retrieved from https://files.eric.ed.gov/fulltext/ED348010.pdf

18. Meijer C.J.W. (Ed.). (2003). Inclusive Education and Effective Classroom Practices. Summary Report. Middelfart, Denmark: European Agency for Development in Special Needs Education. Retrieved from https://www.european-agency.org/sites/default/files/inclusive-education-andclassroom-practices_iecp-en.pdf

19. Miller-Keane, O'Toole M.T. (2005). Miller-Keane Encyclopedia \& Dictionary of Medicine, Nursing \& Allied Health (7th ed.). Philadelphia: WB Saunders.

20. Minkyoung K. (2018). Self-Directed Learning. In B.F. Bruce (Ed.), The School Encyclopedia of Educational Research, Measurement, and Evaluation. SAGE Publications.

21. Mooij T., Driessen G. (2008). Differential Ability and Attainment in Language and Arithmetic of Dutch Primary School Pupils. British Journal of Educational Psychology, 78(3), 491-506. doi: 10.1348/000709907X235981

22. Mooij T., Roeleveld J., Fettelaar D., Ledoux G. (2012). Kwaliteitsbeoordeling van Scholen Primair Onderwijs: het correctiemodel van de inspectie vergeleken met alternatieve modellen [Judging the Quality of Primary Schools: comparing the model of the Education Inspectorate with alternative models], Pedagogische Studiën, 89(5), 272-287. http://pedagogischestudien.nl/download?type=document\&identifier=616725 (in Dutch)

23. Norwich B., Ylonen A., Gwernan-Jones R. (2014). Moderate Learning Difficulties: searching for clarity and understanding. Research Papers in Education, 29(1), 1-19. doi: 10.1080/02671522.2012.729153

24. Pintrich P.R. (2000). The role of orientation in self-regulated learning. In M. Boekaerts, P.R. Pintrich, M. Zeidner (Eds.), Handbook of Self-regulation, San Diego, CA: Academic Press, 451-502.

25. Randi J., Corno L. (2000). Teacher innovations in self-regulated learning. In M. Boekaerts, P.R. Pintrich, M. Zeidner (Eds.), Handbook of Self-regulation, San Diego, CA: Academic Press, 651-685.

26. Recommendation of the European Parliament and of the Council of 18 December 2006 on key competences for lifelong learning. (2006). Official Journal of the European Union, L394/10, 30.12.2006, 10-18. Retrieved from http://data.europa.eu/eli/reco/2006/962/oj

27. Reece I., Walker S. (2016). Teaching, training and learning: A practical guide ( $6^{\text {th }}$ ed.). Business Education Publishers.

28. Resnick L.B. (1987). The 1987 Presidential Address: Learning in school and out. Educational Researcher, 16(19), 13-20. doi: 10.2307/1175725

29. Robinson J.D., Persky A.M. (2020). Developing Self-Directed Learners. American Journal of Pharmaceutical Education, 84(3) Article 847512. doi: 10.5688/ajpe847512

30. Schraw G., Kent J.C., Kendall H. (2006). Promoting Self-Regulation in Science Education: Metacognition as Part of a Broader Perspective on Learning. Research in Science Education (2006)36, 111-139. doi: 10.1007/s11165-005-3917-8

31. Schunk D.H., Zimmerman B. (Eds.). (2011). Handbook of self-regulation of learning and performance. New York: Routledge. doi: 10.4324/9780203839010

32. Taurina A. (2015). Pre-school Age Child Treatment and Awareness about Conservancy of Nature. In V. Dislere (Ed.), The Proceedings of the International Scientific Conference Rural 
Environment. Education. Personality (REEP), 8. Jelgava: LLU, 65-73. Retrieved from https://llufb.llu.lv/conference/REEP/2015/Latvia-Univ-Agricult-REEP-2015proceedings-65-73.pdf

33. Todd M.G., Douglas B.M. (2012). Self-Directed Learning: A Cognitive and Computational Perspective. Perspectives on Psychological Science 7(5), 464-481. doi: 10.1177/1745691612454304

34. Tymms P., Merrel C., Henderson B. (2000). Baseline Assessment and Progress during the First Three Years at School. Educational Research and Evaluation, 6(2), 105-129. doi: 10.1076/13803611(200006)6:2;1-E;F105

35. Veenman M.V.J., Hesselink R.D., Sleeuwaegen S., Liem S.I. E., Van Haaren M.G.P. (2014). Assessing Developmental Differences in Metacognitive Skills With Computer Logfiles: Gender by Age Interactions. Psychological Topics 23(1), 99-113. Retrieved from https://hrcak.srce.hr/120496

36. Wheadon C. (2013). Using Modern Test Theory to Maintain Standards in Public Qualifications in England. Research Papers in Education, 28(5), 628-647. doi: 10.1080/02671522.2012.706631

37. Zimmerman B.J. (1989). Models of self-regulated learning and academic achievement. In B.K. Zimmerman, D.H. Schunk (Eds.), Self Regulated Learning and Academic Achievement: theory, research, and practice. Springer Series in Cognitive Development. New York, NY: Springer-Verlag, 1-25. doi: 10.1007/978-1-4612-3618-4_1

38. Zimmerman B.J. (2002). Becoming a Self-Regulated Learner: An Overview. Theory Into Practice, 41(2), 64-70. doi: 10.1207/s15430421tip4102_2 